\title{
Penerapan dan Analisis Hukum Gadai Lahan Pertanian di Desa Gondanglegi Wetan, Kabupaten Malang
}

\author{
Nur Laila Fiskiyatul Jannah \& Zainudin Fanani \\ Program Studi Hukum Ekonomi Syariah, Fakultas Syariah, \\ Institut Agama Islam Al-Qolam \\ Email: lailafisqiya@gmail.com, \\ zainuddinfanani82@gmail.com
}

\begin{abstract}
This study aims to conduct an analysis related to the application and analysis of agricultural land pawning laws in Gondanglegi Wetan Village, Malang Regency. This research is qualitative using interview method in data collection techniques. The conclusion of this research is that the majority of the community has understood that the pawn transaction of agricultural land is a transaction (contract) that is not justified in Islamic Sharia but in its application the pawn of agricultural land that occurs in Gondanglegi Wetan Village is only based on customary law (adat) which has been applied for generations. On the other hand, there are no provisions regarding regulations or determination of settlement efforts in the event of a breach (breach of contract) in the implementation of pawning agricultural land in Gondanglegi Wetan Village. This is due to the absence of legal force over agricultural land pawning transactions that occur in the community.
\end{abstract}

Keywords: Mortgage, Agriculture, Islamic Law, Islamic Mortgage. 


\section{Pendahuluan}

Menurut bahasa (etimologi), kata mu'amalah adalah bentuk mashdar dari kata 'amala (عامل), yang mengikuti wazan (فلاعل) yang artinya saling bertindak, berbuat, dan beramal. ${ }^{1}$ Secara istilah (syar'an), mu'amalah merupakan suatu sistem dalam dimensi kehidupan. Islam memberikan warna pada setiap dimensi kehidupan manusia, tak terkecuali pada dunia ekonomi, bisnis, dan masalah sosial lainnya. Dalam Syari'ah Islam, kegiatan ekonomi didasari oleh dialektika yang dibangun antara faham materialisme dengan faham spiritualisme. Artinya tidak hanya melulu tentang harta tetapi juga dari mana dan untuk apa harta itu digunakan. ${ }^{2}$

Pengertian harta yang diungkapkan oleh Madzhab Hanafi, adalah sesuatu yang diinginkan atau dicari oleh manusia yang memungkinkan untuk disimpan dan suatu saat dibutuhkan. Sedangkan menurut sebagian ulama lain, harta adalah sesuatu yang berharga atau yang bersifat materi. ${ }^{3}$ Menurut Hanafiyah, harta adalah sesuatu yang berwujud dan dapat disimpan dan sesuatu yang tidak dapat disimpan tidak dapat disebut harta. Menurut Hanafiyah, yang berkaitan dengan manfaat tidak termasuk harta, tetapi manfaat termasuk dalam hak milik. ${ }^{4}$ Sehingga dalam konteks ini bisa disimpulkan bahwa harta adalah yang memungkinkan untuk

\footnotetext{
${ }^{1}$ Rachmat Syafe'i, Fiqib Muamalab; Untuk UIN, STAIN, PTAIS dan Umum, (Bandung: Pustaka Setia, 2001), 14.

2 Ismail N, Fikih Muamalah Klasik dan Kontemporer, 10.

${ }^{3}$ Ibid., Ismail N, 31.

${ }^{4}$ Hendi Suhendi, Figh Muamalah, (Jakarta: Rajawali Pers, 2016), 9.
} 
disimpan oleh manusia, yang pada suatu saat akan dimanfaatkan dalam rangka pemenuhan kebutuhan hidup yang sesuai dengan koridor syari'at.

Karena jika dilihat dari sisi syari'at, tujuan manusia hidup di dunia hanyalah untuk mencapai "falah" yakni kemenangan dan keselamatan akhirat. Maka sebagai muslim yang baik sudah selayaknya jika selalu memegang teguh syariat Islam yang telah ditetapkan, agar tidak termasuk pada kategori orang-orang yang merugi. Hal itu juga dipertegas oleh para ahli ekonomi syari'ah mengenai konsep al-falah yang komprehensif serta bertujuan untuk mengkaji kesejahteraan manusia. ${ }^{5}$

Mekanisme gadai lahan pertanian dapat dinarasikan: "Seorang petani atau orang yang memiliki lahan membutuhkan pinjaman uang, dia meminjam kepada orang lain (hutang) berupa uang atau emas dengan akad gadai atau tanpa akad. Adapun sebagai barang jaminan adalah lahan yang dia miliki. Kemudian lahan tersebut berpindah tangan atau dialihkan atau dikuasai oleh pemberi hutang dan pemberi hutang berhak mengelola serta mengambil manfaat dari lahan tersebut selama hutang belum dibayar"

Titik penting diskursus ini adalah lahan pertanian yang dijaminkan tadi selanjutnya dapat dikelola sebagaimana biasa. Hal ini yang kemudian menjadi asal permasalahan karena lahan yang menjadi

${ }^{5}$ Juhaya S. Pradja, Ekonomi Syariah, Cet. 1, (Bandung: Pustaka Setia, 2012), 57-58. Lihat Juga: Rahmad Hakim, Penerapan Konsep Ta'dib dalam Pembelajaran Ekonomi Syariah, Falah: Jurnal Ekonomi Syariah, Vol. 2, No. 2 (Agustus, 2017), 211225.

122 Vol. 4, No. 2, September 2019 
jaminan tersebut berada dalam penguasaan pemberi hutang (penerima gadai / murtabin) sampai pelunasan hutang. Selama berada di tangan pemberi hutang (penerima gadai / murtabin), hak penggarapan dan penanaman lahan berada di tangan pemberi hutang (penerima gadai / murtabin). Adapun hasil panen yang melimpah dari sawah pun menjadi hak pemberi hutang (penerima gadai / murtabin). Bahkan yang sering terjadi apabila hutang belum terlunasi sampai mencapai waktu bertahun-tahun sehingga hasil keuntungan menggarap lahan yang dijaminkan tersebut melebihi jumlah nilai hutang yang dipinjam oleh yang berhutang (penggadai / rabin).

Mengingat konsep Gadai $(A r-$ Rabn) dalam Islam adalah berdasarkan akad tabarru dan adanya jaminan (Al-Dhaman) merupakan salah satu rukun $A r$-Rabn. Tetapi jika dalam penerapannya dapat menimbulkan kerugian kepada salah satu pihak, maka hal tersebut tidak dibenarkan menurut syara'. Fenomena semacam ini menjadi menarik untuk diteliti mengingat ada dua hal yang bertentangan dalam satu transaksi gadai $(A r-R a h n)$. Juga terkait dengan pemanfaatan lahan yang diambil alih oleh penerima gadai (murtabin) yang tidak sah secara Hukum Islam.

Tidak hanya itu, pada kenyataannya juga terjadi pelanggaran atau sengketa terkait transaksi gadai lahan tersebut. Sedangkan jika dilihat dari kacamata hukum, transaksi gadai lahan pertanian tidak mempunyai kekuatan di mata hukum. Sehingga jika pelanggaran itu terjadi, pihak yang dirugikan akan merasa rugi berlipat-lipat karena untuk menuntut pun ia tak berdaya. Dan sebagaimana temuan peneliti, banyak pelaku gadai khususnya dari pihak penggadai (rahin) 
yang mengeluh merasa dirugikan atas transaksi tersebut. Sebaliknya juga bukan sesuatu yang mustahil jika penerima gadai (murtahin) yang merasakan kerugian atas transaksinya, hal ini dikarenakan adanya pelanggaran (wanprestasi) dari salah satu pihak.

Berangkat dari permasalahan diatas, penelitian ini bertujuan untuk melakukan analisis terkait penerapan dan analisis hukum gadai lahan pertanian di Desa Gondanglegi Wetan Kabupaten Malang.

\section{Landasan Teori}

\subsection{Pengertian Umum Gadai}

Dalam fiqih Islam, transaksi atau akad gadai disebut dengan Ar-Rahn. Ar-Rahn menurut bahasa adalah Al-Tsubut wa Al-Dawam yaitu tetap dan kekal. ${ }^{6}$ Kata (jَ) rabinah diambil dari kata (jَنَنَ) rahana dengan aneka ragam makna. Antara lain jika diartikan secara asal bahasa, gadai yakni sesuatu yang dijadikan jaminan guna memperoleh utang. Lazimnya adalah bahwa sesuatu itu ditahan oleh pemberi utang, dan dari sinilah kata tersebut diartikan dengan sesuatu yang ditahan.

Gadai $(r a h n)$ secara bahasa sebagaimana diungkapkan di atas adalah tetap, kekal, dan jaminan. Sedangkan dalam pengertian istilah adalah menahan sejumlah barang atau harta yang diserahkan sebagai jaminan secara hak, dan dapat diambil kembali sesudah ditebus (lunas

${ }^{6}$ Wahbah Zuhayli, Fiqh Islam wa Adillatuhu, Jilid 6 (Damaskus: Darul Fikir, 2000), 4207.

124 Vol. 4, No. 2, September 2019 
hutang). ${ }^{7}$ Gadai (rahn) adalah menahan salah satu harta milik (rabin) sebagai jaminan (marbun) atas hutang (marbun bibi) yang diterimanya. Dengan syarat marbun tersebut harus memiliki nilai ekonomis. ${ }^{8}$ Adapun ulama Syafi'iyah dan Hanabillah mendefinisikan gadai sebagai berikut:

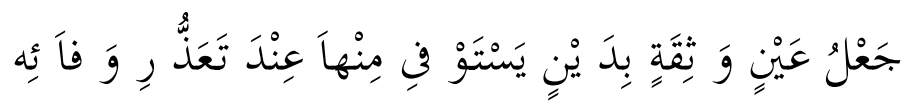

"Menjadikan suatu barang sebagai jaminan butang yang dapat dijadikan pembayaran butang apabila yang berbutang tidak bisa membayar butangnya itu".'

Selain itu, gadai menurut ketentuan dalam hukum adat adalah menyerahkan tanah untuk menerima sejumlah uang secara tunai, dengan ketentuan orang yang berhutang tetap berhak atas pengembalian tanahnya dengan jalan menebusnya kembali (melunasi hutangnya). ${ }^{10}$ Dari berbagai pengertian gadai di atas, dapat diambil pengertian bahwa gadai adalah transaksi hutang piutang antara dua orang atau lebih yang disertai dengan jaminan. ${ }^{11}$

Gadai (rabn) pada umumnya adalah dihukumi mubah, berdasarkan dalil Al-Qur'an, Hadits dan Ijma'. Dasar gadai (rabn)

7 Sutan Remi Sjahdeni, Perbankan Syariab: Produk-produk dan Aspek Hukumnya, (Jakarta: Jayakarta Agung Offset, 2010), 329.

${ }^{8}$ Muhammad Syafi'i Antonio, Bank Syariah dari Teori ke Praktek, (Jakarta: Gema Insani Press, 2001), 128.

${ }^{9}$ Siah Khosyi'ah, Fiqh Mualamah Perbandingan, (Bandung: CV Pustaka Setia, 2014), 188.

10 Dadan Muttaqien, Aspek Legal Lembaga Keungan Syariah, cetakan ke-1, (Yogyakarta: Safira Insani Press, 2009), 106-107.

${ }^{11}$ Sapiudin Shidiq, Fikib Kontemporer, (Jakarta: Kecana, 2017), 259. 
termaktub dalam firman Allah SW'T Surat Al-Baqarah ayat 283 berikut:

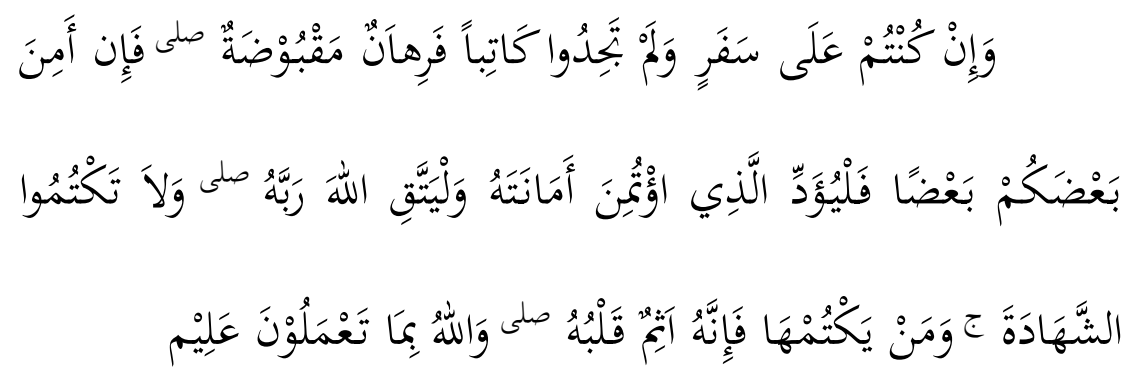

Artinya: "Jika kamu dalam perjalanan (dan bermu'amalah tidak secara tunai) sedangkan kamu tidak memperoleh seorang penulis, maka hendaklah ada barang tanggungan yang dipegang (oleh yang berpiutang). Akan tetapi jika sebagian kamu mempercayai sebagian yang lain, maka bendaklah yang dipercayai itu menunaikan amanatnya (butangnya) dan hendaklab ia bertakwa kepada Allah Tubannya; dan janganlah kamu (para saksi) Menyembunyikan persaksian. Dan barang siapa yang menyembunyikannya, maka sesunggubnya ia adalah orang yang berdosa hatinya; dan Allab Maha mengetabui apa yang kamu kerjakan". ${ }^{2}$

Esensi dari ayat tersebut adalah bahwa gadai boleh dilakukan baik ketika dalam bepergian maupun tidak, boleh juga tidak mengambil jalan gadai jika merasa yakin bahwa dirinya mampu melunasi hutang tersebut dengan pasti. ${ }^{13}$ Dan untuk memudahkan jalannya bermuamalah, Islam memberikan kemudahan bagi

12 QS. Al-Baqarah (2): 283.

13 Abu Bakar Zabir Al-Jazairi, Tafsir Al-Aisar Buku 1, cetakan ke-5, (Jakarta: Darus Sunnah Press, 2013), 284. 
ummatnya untuk dapat bertransaksi secara lisan sekaligus menyerahkan barang jaminan sebagai tanda saling percaya. Barang jaminan tersebut telah menjadi amanat si pemberi hutang, dan yang berhutang mempunyai amanat berupa hutang yang harus diselesaikan (dilunasi/dibayar). Sehingga kedua belah pihak harus menunaikan amanatnya masing-masing dengan sebaik mungkin sebagai tanda bukti taqwa kepada Allah SWT.

Rasulullah bersabda sebagaimana disebutkan dalam sebuah hadits, yang artinya:

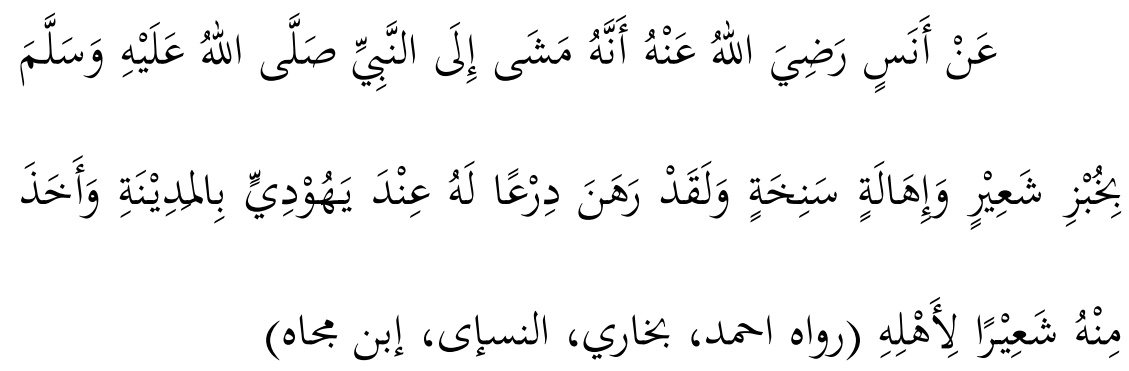

"Dari Anas, ia berkata: Rasullullah SAW menggadaikan baju besi kepada seorang Yahudi di Madinah, sebagai jaminan ketika beliau mengambil (meminjam) gandum dari orang Yahudi tersebut untuk keluarganya". (HR. Ahmad, Bukhari, An-Nasa'i, dan Ibnu Majah). ${ }^{14}$

\section{Penerapan dan Analisis Hukum Gadai Lahan Pertanian}

${ }^{14}$ Hasbi Ash Shiddieqy, Koleksi Hadis-Hadis Hukum, Cet. 3, Jakarta: PT Pustaka Rizki Putra, 2001), 130. 
Pinjam meminjam uang sangat sering dijumpai dalam kehidupan sehari-hari. Pinjam meminjam dengan berbagai bentuk dan cara pelaksanaan, di antaranya pinjam meminjam dengan disertai barang jaminan (agunan) yang ditangguhkan atau disebut dengan gadai. Dalam kasus tersebut terjadilah hubungan baik antara peminjam dan yang memberi pinjaman dengan asas tolong menolong (ta'awun). Dan yang sangat penting untuk digaris bawahi adalah bahwa dalam transaksi apapun tidak dibenarkan menurut syariat Islam adanya salah satu pihak yang dirugikan atau pihak lainnya mendapat keuntungan sebesar-besarnya.

Sama halnya dengan yang terjadi pada penerapan gadai. Secara etimologi, kata gadai $(A r-R a h n)$ berarti tetap, kekal, dan jaminan. Akad rahn dalam istilah hukum positif disebut dengan barang jaminan, agunan dan rungguhan. Dalam Islam rabn merupakan sarana saling tolong menolong (ta'awun) bagi umat Islam dengan tanpa adanya imbalan jasa. ${ }^{15}$

Dalam penelitian ini, pembahasan mengenai gadai lebih spesifik kepada gadai lahan pertanian seperti yang telah disebutkan dalam point rumusan masalah. Dan sebagaimana yang sedang marak terjadi di Desa Gondanglegi Wetan, karena mayoritas penduduk bermata pencaharian sebagai petani tebu juga lahan tebu yang ada di Desa Gondanglegi Wetan terhitung luas. Sehingga terjadilah gadai

${ }^{15}$ Nasrun Haroen, Fiqh Mu'amalah, cetakan ke-1 (Jakarta: Gaya Media Pratama, 2000), 51.

128 Vol. 4, No. 2, September 2019 
$(r a h n)$ lahan pertanian antara petani satu dengan lainnya, atau juga antara petani dengan yang bukan petani.

Pada dasarnya gadai $(r a b n)$ bersifat sosial dengan tujuan saling membantu antara pihak yang membutuhkan uang (penggadai / rabin) dengan pihak penerima gadai (murtabin). Dan secara umum, untuk luas serta letak lahan yang dijadikan jaminan tidak boleh dijadikan pertimbangan. Agar dalam penerapannya sesuai dengan hukum gadai yang diakui dan tidak bertentangan dengan hukum Islam, sehingga transaksi yang akan dilakukan sah secara hukum sebagaimana yang berlaku.

Sedangkan yang terjadi di kalangan masyarakat Desa Gondanglegi Wetan terdapat dua perspektif yang berbeda antara masyarakat kalangan menengah ke atas dan menengah ke bawah. Bagi kalangan menengah ke atas gadai dipandang sebagai suatu kegiatan atau interaksi sosial yang dijadikan ajang bisnis dan dapat menghasilkan profit, dalam arti lain sebagai kepentingan komersial, sebagian yang lain ada yang memandang gadai sebagai sarana untuk menolong sesama. Dan bagi kalangan menengah ke bawah gadai dipandang sebagai suatu kewajaran ketika seseorang membutuhkan pinjaman berupa uang secara tunai dalam keadaan mendesak sementara yang mereka punya hanya lahan pertanian, sehingga menggadaikan lahannya adalah alternatif yang dianggap mudah untuk ditempuh.

Akad gadai lahan pertanian yang terjadi di kalangan petani Desa Gondanglegi Wetan umumnya masih dilakukan antar individu. Mengenai mekanisme yang digunakan tidak merujuk pada aturan 
tertentu, baik itu secara hukum positif maupun fiqih Islam. Mereka melaksanakan gadai lahan pertanian berdasarkan hukum adat yang timbul dari budaya atau kebiasaan yang berlaku di kalangan masyarakat yang sejak lama dilakukan secara turun temurun. Dalam arti lain, tidak ada pelafalan ijab maupun qabul antara kedua belah pihak ketika bertransaksi.

Adapun dalam praktik atau penerapannya, tidak ada pengaturan mengenai ketentuan pengelolaan selama gadai tersebut berlaku. Pada praktiknya hanya berjalan apa adanya. Juga mengenai waktunya tidak ditentukan di awal perjanjian, yakni masa gadai tersebut tetap akan berjalan selama si penggadai (rabin) belum dapat melunasi hutangnya terhadap penerima gadai (murtahin). Dan jika hutang tersebut tak kunjung dilunasi oleh rabin, bukan tidak mungkin jika murtahin akan mengambil alih kepemilikan dari lahan pertanian yang menjadi jaminan gadai atau menjualnya kepada orang lain.

Baik dari pihak rabin maupun murtabin, baik yang sifatnya sosial maupun komersial ditentukan dari letak dan luasnya lahan yang akan dijadikan jaminan. Hal ini yang dijadikan pertimbangan untuk menentukan jumlah atau besarnya hutang yang akan diberikan murtabin kepada rabin. Praktik perjanjian gadai yang demikian sangatlah bertentangan dengan Hukum Islam, karena sudah tidak lagi sesuai dengan hakikat akad gadai yang seharusnya bersifat sosial.

Seperti H. Ismail yang menggadaikan lahan pertaniannya berupa lahan tebu; "Saya menggadaikan laban tebu kepada tetangga saya, karena saat itu saya sedang membutubkan uang cash sejumlab Rp. 50.000.000,- dalam waktu yang cepat untuk. melunasi hutang anak saya yang 
sudah jatub tempo di beberapa Bank. Sehingga saya menggadaikan lahan tebu dengan nilai tersebut yang mempunyai luas $300 \mathrm{~m}$ dan pada 2 tahun kemudian saya tebus lahan milik saya itu. Dan saya kapok pernah berurusan dengan hal seperti itu". ${ }^{16}$

Juga seperti yang terjadi pada Bapak Suparman, ia menggadaikan lahan tebunya kepada janda kaya dengan alasan; "Saya pernah menggadaikan laban tebu luas $200 \mathrm{~m}$ senilai Rp. 30.000.000,- karena saat itu saya sedang butuh uang untuk membiayai anak saya yang man dikbitan. Semoga itu menjadi yang terakbir, saya tidak, mau lagi". ${ }^{17}$

Lain halnya dengan yang terjadi pada Bapak Supardi, yang memang malang melintang di bidang gadai lahan pertanian; "Saya telah beberapa kali menggadaikan maupun menerima gadai lahan tebu itu karena beberapa alasan. Pertama, saya menggadaikan lahan tebu dengan niat menolong orangyang sedang membutubkan dana dari hasil mengelola laban tebu yang saya gadaikan tersebut. Kedua, juga saya menerima gadai laban tebu dari orang lain sebagai cara untuk saya mendapatkan keuntungan dan memutar usaha saya yang memang di bidang pertanian khususnya tebu. Dan dengan harga yang sesuai dengan luas atau ukuran lahannya". ${ }^{18}$

Dengan latar belakang yang berbeda, manusia akan memiliki cara dan karakteristik yang berbeda pula dalam melaksanakan aktivitas ekonomi. Perbedaan ini yang mendatangkan keragaman tingkat kebutuhan serta tuntutan masing-masing individu. Suatu kondisi yang menurut pribadi seseorang adalah biasa saja, bisa saja

\footnotetext{
16 Ismail, Wawancara (Karang Asem, 16 Maret 2019).

17 Suparman, Wawancara (Karang Asem, 17 Maret 2019).

18 Supardi, Wawancara (Wates, 18 Maret 2019).
} 
menurut seseorang yang lain adalah luar biasa. Dan suatu kondisi yang terbilang menguntungkan seseorang, bisa saja justru merugikan bagi sebagian yang lain. Hal ini adalah kasus relatif yang tidak bisa hanya dipandang dari satu sisi.

Selayaknya manusia yang mempunyai keahlian dan keterampilan masing-masing seharusnya satu dan lainnya saling mengisi, sehingga konsep kesejahteraan umat tersebut dapat dicapai. Tetapi dalam kenyataannya, yang terjadi pada masyarakat Desa Gondanglegi Wetan justru berkebalikan dengan konsep-konsep Ekonomi Islam yang menjunjung tinggi kesejahteraan dan kemashlahatan umat.

Hal ini terbukti pada praktek gadai lahan pertanian yang sudah terbiasa dilakukan sejak dahulu. Meskipun mayoritas masyarakat mengetahui ketimpangan terkait untung rugi yang akan dialami, juga bahaya akan sesuatu yang tidak diinginkan. Justru sesuatu yang memiliki nilai resiko tinggi pun dilakukan dengan tegap dada dengan alasan alternatif yang mudah bagi semua masalah yang tengah dialami. Kasus semacam ini adalah bukti adanya kerenggangan antara konsep dengan realita yang terjadi.

Apalagi secara akad pun sama sekali tidak dapat dipertaruhkan secara syar'i. Terkadang ada yang tidak dibatasi waktu dan aturan-aturan sebagaimana yang terdapat dalam syarat dan rukun sah akad gadai $(r a h n)$ sesuai dengan Hukum Islam. Bukan tidak mungkin jika selama pelaksanaan yang dijalani adalah transaksi yang haram dalam pandangan Islam dan Allah SWT, dikarenakan ketidak 
jelasan akad dan ketidaksesuaian dengan ketentuan-ketentuan syara' yang lain.

Seperti yang diyakini Bu Farida; "Sebenarnya gadai tebu dan sejenisnya itu tidak boleh dan sangat dilarang dalam Islam. Saya pun menyesali apa yang telah dilakukan oleh Ibu dan Kakak kandung saya sendiri. Mereka berdua menerima gadai (murtabin) tanpa pengetabuan saya dari seseorang dengan alasan hasil dari pengelolaan laban tebu tersebut untuk melunasi pembayaran mobil. Padabal Almarbum Ayah saya sangat jelas menentang praktek tersebut, tetapi Ibu dan Kakak saya rupanya terbuai dengan kebutuhan yang dianggapnya mendesak". ${ }^{19}$

Demikian juga Bu Aminah; "Orang-orang yang pernah terlibat urusan gadai lahan pertanian itu pasti menyesal. Karena resiko rugi, belum lagi kalau hasil panennya tidak sesuai. Yah.. namanya juga pertanian, kan hasilnya gak. nentu tergantung kondisi alam". ${ }^{20}$

Pada umumnya resiko kerugian yang paling nampak adalah yang dialami oleh penggadai (rabin), meskipun bagi masyarakat merasa baik-baik saja tetapi sesungguhnya mereka tidak menyadari bahwa dirinya telah dirugikan atas transaksi gadai tersebut. Berbeda dengan penerima gadai (murtahin) yang pada umumnya selalu menjadi pihak yang mendapatkan keuntungan. Logikanya, kerugian yang dimaksud bagi rahin adalah; mereka mendapatkan uang yang dibutuhkan tetapi kehilangan hasil kelola dari lahan yang mereka gadaikan selama beberapa waktu. Dan bagi murtabin, dikatakan

${ }^{19}$ Faridatul Kholila, Wawancara (Kendayaan, 20 April 2019).

20 Siti Aminah, Wawancara (Karang Asem, 20 April 2019). 
untung karena mereka mengambil alih hak kelola dari lahan tersebut dan mendapat uang piutang (tebusan) di kemudian hari, jika dikalkulasikan keuntungan ini bisa mencapai dua atau tiga kali lipat tergantung kondisi alam sebagai penentu hasil kelola pertanian.

Seperti yang dialami Bu Alfiyah; "Saya menerima gadai tebu seorang tetangga, dengan saya memberikan pinjaman uang kepadanya sejumlah Rp. 50.000.000,- dalam jangka waktu 2 tabun. Dibilang senang ya senang, dibilang untung ya memang untung. Kalau suatu saat ada lagi orang yang datang untuk menggadaikan tebunya, mungkin saya mau". ${ }^{21}$

Berbeda dengan Bu Sri yang mengungkapkan; "Saya menerima gadai tebunya orang itu dan saya sangat menyesal. Sudah saya kehilangan uang Rp.20.000.000,-juga masib rugi karena ternyata tebu yang saya terima sebagai barang gadai itu adalab laban tebu yang rusak. Dan saya baru tau kalau gadai tebu itu tidak boleh setelah saya selesai". ${ }^{22}$

Ada juga H. Subairi yang memiliki pengalaman berbeda dengan lainnya; "Kalau saya sering menerima gadai dari orang-orang, babkan bisa dikatakan kalau saya sudah abli di bidang itu. Memang saya menjadikan praktek gadai tebu itu sebagai bisnis. Tau sendiri saya juga punya usaba pabrik. penggilingan gula merah, saya rasa tidak ada masalah selama ini meskipun saya sendiri tau bahwa itu tidak boleh". 23

Segala sesuatu yang terjadi di dunia ini sesungguhnya memiliki penjelasan. Ada akibat pasti ditimbulkan oleh sebab. Munculnya sebuah resiko tentu disebabkan oleh adanya akar permasalahan.

21 Alfiyah, Wawancara (Wates, 17 Maret 2019).

22 Sri Rahayu, Wawancara (Karang Asem, 17 Maret 2019).

23 Subairi, Wawancara (Wates, 19 Maret 2019).

134 Vol. 4, No. 2, September 2019 
Sebagai seorang mukmin, seharusnya lebih bijak dalam menentukan sikap. Bahwa Allah telah menentapkan peraturan-peraturan sebagaimana yang dijelaskan dalam Fiqib Islam bukan sembarang peraturan, tentu semua aturan yang ditetapkan Allah adalah sebaikbaiknya ketentuan dan juga demi kebaikan umat manusia sendiri.

Resiko yang ditimbulkan dari adanya akad gadai lahan pertanian tersebut, adalah disebabkan oleh adanya utang piutang. Di sisi lain, syari'at Islam telah menggariskan bahwasanya kontrak atau transaksi yang terjadi dalam utang piutang (qard) adalah didasarkan atas faktor irfaq (rasa kasihan/simpati) dengan motivasi untuk menolong sesama. Maknanya, akad qardl sejatinya adalah murni perbuatan kebajikan dengan niat yang mulia. Sehingga yang seharusnya akad qardl itu diperuntukkan bagi kaum faqir yang benarbenar membutuhkan pertolongan.

Masalah yang dapat dideteksi dari adanya akad gadai (rahn) adalah terlanjur melekatnya kepercayaan masyarakat terhadap budaya yang dianut dari nenek moyangnya. Hal ini yang kemudian menjadi pemicu lalainya masyarakat terhadap Fiqih Islam yang seharusnya menjadi pedoman umat muslim dalam segala aktivitas. Karena sejak masa Wali Songo dahulu, budaya dan masyarakat adalah dua hal yang sangat sulit untuk dipisahkan dan menjadi permasalahan yang pelik untuk dipecahkan.

Pada dasarnya, status marbun tidak boleh diambil manfaatnya baik oleh rabin maupun murtahin kecuali jika mendapat izin dan berdasarkan persetujuan di antara keduanya. Hak murtabin terhadap marbun hanyalah sebatas menahan, tidak berhak mengambil hasil 
maupun menguasainya. Dan selama marbun ada di tangan murtabin sebagai jaminan dari marbun bibi, rabin juga tidak berhak untuk mengambil manfaat dari marbun.

Menurut Muhammad Ali Hasan, barang yang dijadikan jaminan seperti sawah, kebun atau ladang hendaknya untuk diolah dan dimanfaatkan supaya tidak mubadhir, dan mengenai hasilnya dapat dibagi antara rabin dan murtahin berdasarkan atas kesepakatan bersama. Ada satu hal yang sangat penting yang perlu diingat, bahwa hasilnya tidak boleh menjadi hak sepenuhnya murtahin seperti yang berlaku dalam masyarakat dan praktik seperti inilah yang harus diupayakan supaya lurus dan sejalan dengan ajaran Islam. ${ }^{24}$

Adapun mengenai boleh tidaknya marbun diambil manfaatnya oleh rabin maupun murtahin, Ulama' empat madzhab (yakni; madzhab Hanafi, madzhab Maliki, madzhab Syafi'i dan madzhab Hambali) dalam hal ini memiliki perbedaan pendapat sebagaimana penjelasan berikut:

a) Madzhab Hanafi

Madzhab Hanafi berpendapat bagi rabin, bahwa rabin selaku pihak yang menggadaikan tidak berhak mengambil manfaat dari marbun sampai perjanjian gadai itu berakhir, kendati pun marbun tersebut sah adalah hak miliknya. Karena selama perjanjian gadai tersebut berlangsung, posisi marbun adalah berada di tangan murtabin dan ditahan oleh murtabin. Ketika rahin mengambil manfaat dari

${ }^{24}$ M. Ali Hasan, Berbagai Macam Transaksi Dalam Islam (Figh Muamalat), (Jakarta: PT Raja Grafindo Persada, 2003), 258.

136 Vol. 4, No. 2, September 2019 
marhun tanpa seizing murtahin, berarti ia telah melakukan perbuatan yang melanggar hukum (ghashab).

Sedangkan bagi murtahin, Hanafiyyah berpendapat bahwa juga tidak diperbolehkan untuk mengambil manfaat dari marbun karena hak murtahin hanya sebatas menahan bukan memanfaatkan atau menguasai kecuali atas izin rabin.

\section{b) Madzhab Maliki}

Madzhab Maliki menetapkan bagi rahin, bahwa rabin tidak boleh lagi mengambil manfaat dari marbun. Madzhab Maliki juga menetapkan bahwa izin murtabin terhadap rabin untuk dapat memanfaatkan marbun dinilai sebagai sebab batalnya akad rahn, karena pemberian izin ini dianggap sebagai pelepasan hak murtabin terhadap marbun.

Sedangkan untuk status pemanfaatan marbun bagi murtabin, ulama' Malikiyah membedakannya menjadi 2 (dua) bagian yakni:

1) Hutang yang bersifat qardh; bahwa murtabin tetap tidak diperbolehkan untuk mengambil manfaat dari marbun sekalipun atas izin rabin karena hal itu berarti termasuk dalam hutang yang menarik kemanfaatan dan bukan atas tujuan sosial.

2) Hutang yang bersifat (disebabkan) karena jual beli atau mu'awadah (pertukaran); artinya diperbolehkan bagi murtabin untuk memanfaatkan apabila rabin mengizinkan dan pemanfaatannya harus disertai penentuan batas waktu yang 
jelas agar tidak mengandung unsur jabaalah yang bisa merusak akad.

Adapun mengenai hasil marhun sebagai contoh dalam kasus gadai lahan pertanian dalam penelitian ini, ulama' Malikiyah berpendapat bahwa hasil marhun dan segala sesuatu yang dihasilkan dari padanya adalah hak rahin. Namun murtahin dapat mengambil manfaat marhun dengan syarat; hutang yang berasal dari jual beli, pihak murtahin yang meminta hak pemanfaatan menjadi miliknya, dan jangka waktu pengambilan manfaat telah ditentukan dengan adil serta tidak bernilai merugikan salah satu pihak.

c) Madzhab Syafi'i

Berbeda dengan pendapat ulama' madzhab lainnya, madzhab Syafi'i berpendapat bahwa rabin boleh memanfaatkan marbun selama tidak mengurangi atau merusak nilai materiil dari marbun. Kebolehan ini berdasar kepada dalil hukum bahwa manfaat dan hasil dari marbun adalah tetap hak milik rabin serta tidak bisa dikaitkan dengan hutang yang ditanggungnya.

Sebaliknya bagi murtabin, ulama' Syafi'iyah berpendapat bahwa murtabin tidak boleh mengambil manfaat dari marbun karena merujuk kepada hak kepemilikan mutlak atas marbun adalah milik rabin.

d) Madzhab Hambali

Ulama' madzhab Hambali berpendapat bahwa, dalam syara' tidak diperbolehkan menelantarkan atau menyia-nyiakan barang gadai (marbun). Oleh karenanya, baik rabin maupun murtabin hendaknya melakukan kesepakatan mengenai pemanfaatan marbun. Tetapi ketika

138 Vol. 4, No. 2, September 2019 
kesepakatan itu tidak dapat dicapai pada batas kebolehan pemanfaatan, maka marbun harus dibiarkan karena merupakan barang yang tertahan dari pemanfaatan sampai rabin mampu melunasi hutangnya.

Ulama' Hanabilah mengatakan jika marbun bukan termasuk hewan atau kendaraan, artinya jika marbun adalah benda-benda yang tidak memerlukan biaya pemeliharaan, maka dalam Hukum Islam melarang murtabin untuk mengambil manfaat dari marbun tanpa seizin rabin.

Merujuk pada pendapat madzhab Maliki yang membagi sifat hutang (qardh) menjadi dua kategori, yakni qardh yang bersifat qardh dan qardh yang bersifat jual beli. Rupanya pendapat ini menimbulkan kesalahpahaman di kalangan masyarakat. Seperti temuan peneliti ketika wawancara kepada Bapak Supardi, beliau yang mengaku sudah sangat sering melakukan transaksi gadai lahan pertanian itu mengaku baik-baik saja dan tidak merasa melakukan perbuatan yang dilarang.

"Gadai sawah, tebu, tanah atau apapun itu boleh. Saya berani melakukannya karena guru saya juga mengizinkan asalkan menggunakan akad yang jelas yaitu akad jual beli".

Sebenarnya jika dikaji lebih lanjut bukan akadnya menggunakan akad jual beli, tetapi sebagaimana yang dimaksudkan oleh ulama madzhab Maliki adalah hutang (qardh) yang berasal dari jual beli. Misalnya: Irsyad ingin membeli sesuatu kepada Asyfiyah, tetapi Irsyad tidak mempunyai cukup uang untuk membelinya,

${ }^{25}$ Supardi, Wawancara (Wates, 18 Maret 2019). 
karenanya Irsyad menghutang barang tadi dengan memberikan barang miliknya sebagai jaminan. Menjaminkan (menggadaikan) barang dengan kronologi yang seperti itulah yang dibenarkan dalam Islam dan diperbolehkan bagi murtabin untuk memanfaatkan marbun jika atas izin rabin dan disertai dengan ketentuan batas waktu yang jelas.

Sedangkan sebagian ulama' ahli fiqih madzhab Hanafi berpendapat bahwa tidak ada jalan yang memperbolehkan murtabin untuk mengambil manfaat dari marbun sekalipun atas izin rabin. Karena termasuk riba atau mengandung unsur symbhat. Namun mayoritas dari mereka sepakat jika rahin sebagai pemilik mutlak marhun mengizinkan murtahin untuk memanfaatkan, maka murtahin boleh untuk memanfaatkan marhun dengan syarat hal tersebut tidak disyaratkan ketika akad. Sebaliknya jika hal tersebut disyaratkan ketika akad, maka hal pemanfaatan gadai tersebut termasuk riba.

Seluruh ulama' sepakat bahwasanya riba merupakan kejahatan besar dan termasuk kabiiratun minal kabaair (dosa yang sangat besar di antara dosa-dosa besar yang lain). ${ }^{26}$ Riba qardh (riba jabiliyah / riba nasi'ab) itu diharamkan menurut Al-Qur'an. Oleh karena itu, seluruh ulama' tanpa terkecuali telah sepakat bahwa riba al-qardh itu diharamkan dalam Islam. ${ }^{27}$

${ }^{26}$ Ahmad Mustofa, Et.al., Reorientasi Ekonomi Syari'ah, (Yogyakarta: UII Press, 2014), 1.

27 Adiwarman A. Karim dan Oni Sahroni, Riba, Gharar dan Kaidah-kaidah Ekonomi Syariah: Analisis Fikih dan Ekonomi, (Jakarta: Rajawali Pers, 2018), 64.

140 Vol. 4, No. 2, September 2019 
Riba qardh adalah riba yang terjadi pada transaksi hutang piutang yang tidak memenuhi kriteria, maksudnya adalah jika keuntungan muncul bersamaan dengan resiko (al ghunmu bil ghurmi) dan hasil usaha muncul bersamaan dengan biaya (al kharraj biddhaman). Sehingga kewajiban menanggung beban dalam hal ini selalu bertambah hanya karena berjalannya waktu. ${ }^{28}$

Perjanjian gadai pada dasarnya adalah perjanjian hutang piutang hanya saja dalam gadai ada jaminannya, dan riba akan terjadi dalam gadai apabila:

a) Ketika akad gadai berlangsung ada ketentuan bahwa rahin harus memberikan tambahan kepada murtabin, ketika suatu saat nanti akan membayar hutangnya.

b) Ketika akad ditentukan beberapa syarat, kemudian syarat tersebut dilaksanakan.

Apabila rabin tidak mampu membayar hutangnya hingga jatuh tempo, kemudian murtabin menjual barang gadaian tanpa izin dan tidak memberitahukan harga marbun kepada rabin. ${ }^{29}$

\section{Upaya Penyelesaian Sengketa Gadai Lahan Pertanian}

Dalam setiap transaksi atau perjanjian, baik prestasi maupun wanprestasi adalah dua hal yang sangat lazim terjadi. Prestasi adalah sesuatu yang wajib dipenuhi dalam setiap perikatan. Dengan kata lain, prestasi adalah objek perikatan. Sedangkan wanprestasi adalah tidak

28 Adiwarman Karim, Bank Islam: Analisis Fikih dan Keuangan, (Jakarta: Raja Grafindo Persada, 2004), 37.

${ }^{29}$ Hendi Suhendi, Figh Muamalah, (Jakarta: Rajawali Pers, 2010), 111. 
terpenuhinya sesuatu yang diwajibkan seperti yang telah ditetapkan dalam perikatan. Singkatnya wanprestasi adalah perbuatan melawan hukum, melanggar perjanjian, menyalahi aturan, dan sebagainya.

Demikian halnya dalam gadai lahan pertanian yang diterapkan di Desa Gondanglegi Wetan, bukan tidak mungkin jika rabin maupun murtabin melakukan suatu perbuatan yang melawan hukum atau melanggar perjanjian. Seperti yang penulis temukan di lapangan saat penggalian data, Pak Rosyadi menjadi murtabin sawah dari salah satu kerabatnya yang mengaku tertipu.

"Saya menerima gadai dari kerabat mertua dengan pinjaman Rp. 5.000.000,-, sebenarnya saya tau kalau hal itu dilarang tapi tetap dilakukan atas paksaan mertua dan karena alasan kerabat. Akbimya, saat gadai itu sedang berjalan tiba-tiba pemilik (kerabat) saya itu menjual sawahnya tanpa sepengetahuan kami. Saat itu saya mendapat dua kali kelola dengan basil Rp. 2.800.000,- dan bukan banya itu, kerabat saya tadi tidak mau membayar hutang sisanya dengan alasan tidak, punya uang sepeser pun". ${ }^{30}$

Berbeda dengan Ibu Sri, yang ketika dilakukan wawancara beliau mengatakan tidak terjadi pelanggaran tetapi sebenarnya terjadi. Dalam arti lain beliau tidak menyadari jika sebenarnya ia telah dicurangi oleh rekan rabinnya.

"Saya menerima gadai dari tetangga, tetapi setelah dalam masa kelola ternyata tebunya itu bukan tebu yang bagus. Tanabnya tidak bagus, benib tebunya juga bukan benih yang bagus sehingga tebunya selalu rusak. Uang

${ }^{30}$ Bawon Rosyadi, Wawancara (Karang Asem, 16 Maret 2019).

142 Vol. 4, No. 2, September 2019 
pinjaman yang semula Rp. 20.000.000,- juga tidak dikembalikan oleh orangnya. Saya mendapat hasil kelola tebu tersebut Rp. 16.000.000,““.31

Ada juga yang melakukan kecurangan dengan alasan akad, yakni Bapak Pondi; "Tidak ada perjanjian di awal jika uang yang saya pinjam harus dikembalikan, jadi ya saya rasa saya tidak punya keewajiban untuk mengembalikean". 32

Ketiga contoh kasus di atas, adalah bentuk wanprestasi dari perjanjian gadai yang mereka lakukan. Kasus pertama dan kedua adalah bentuk kecurangan yang dilakukan oleh pihak rahin, meskipun pada kasus kedua pihak murtahin tidak menyadari jika dirinya telah dicurangi. Sedangkan pada kasus ketiga, alasan akad yang sebenarnya jika dipandang dari segi Hukum Islam adalah akad tersebut tidak lagi merupakan akad gadai melainkan sewa menyewa. Tetapi dalam penerapannya karena yang dilafalkan pada perjanjian awal dan yang difahami oleh kedua belah pihak adalah akad gadai, maka pemikiran egois yang berwujud pada perbuatan tersebut adalah perbuatan yang melanggar (wanprestasi).

Kemudian terkait upaya penyelesaiannya bagaimana? Rupanya hal ini sangat menarik untuk dikaji. Sebab, penerapan gadai yang sejatinya dilarang tetapi tetap dilakukan, ketika terjadi wanprestasi maka akan menjadi lemah di mata hukum. Jangankan lembaga hukum, di kalangan Pemerintahan Desa saja sangat dimentahkan karena dipandang sebagai sebuah kebodohan telah

${ }^{31}$ Sri Rahayu, Wawancara (Karang Asem, 17 Maret 2019).

32 Pondi, Wawancara (Karang Asem, 17 Maret 2019). 
melakukan perbuatan yang sudah jelas dilarang terlebih juga resiko kerugiannya.

Namun pada kasus Bapak Rosyadi, beliau masih sempat membawa permasalahannya kepada tingkat Desa. Yakni beliau mendatangkan seorang penengah yang menjadi pendamai diantara kedua belah pihak. Sehingga rahin yang tadinya berniat tidak akan membayar hutangnya, seolah mempunyai stimulus berupa rasa takut akan tertuntut lebih jauh jika ia tetap bersikeras tidak mau membayar hutangnya.

"Saya membawa kasus tersebut kepada salah satu perangkat Desa, sehingga uang saya dikembalikan Rp. 2.000.000,-. Meskipun begitu jika diperbitungkan, saya masib tetap rug?". ${ }^{3}$

Hal ini terjadi mertua dari murtahin (Bapak Rosyadi) adalah sosok yang mempunyai pengaruh di wilayah tempat tinggalnya. Jika tidak, maka sekelas perangkat Desa pun enggan untuk turut campur dalam permasalahan yang jelas terlarang tersebut. Seperti yang diungkapkan oleh Pak Bayan (Ahmad Zaini);

"Gadai sawah, tebu atau apapun itu, dalam Islam sudah jelas dilarang. Semua orang juga telah mengetahui, meskipun nyatanya mereka tetap melakukan. Tetapi jika terjadi sesuatu, Pemerintahan Desa tidak akan mau ikut campur. Masyarakat pun demikian, tidak akan berani melapor karena memang yang dilakukan itu salab". ${ }^{34}$

33 Bawon Rosyadi, Wawancara (Karang Asem, 16 Maret 2019).

${ }^{34}$ Ahmad Zaini, Wawancara (Karang Asem, 21 Maret 2019).

144 Vol. 4, No. 2, September 2019 
Sama halnya dengan ungkapan Pak Kepala Dusun Wates (Suwarno); "Babkan penduduk yang tinggal di sekitar saya, orang terdekat saya tidak akan berani datang jika mereka membawa permasalaban gadai itu". ${ }^{35}$ Juga Pak Juru Tulis Desa (Shohib) yang sangat keras menentang; "Kalau ada saya mengetabui orang melakukan gadai sawah itu, langsung saya bawa ke Kantor Polisi ?. 36

Sudah sangat jelas, jika di tingkat Pemerintahan Desa saja tidak ada ruang bagi rabin maupun murtabin yang merasa dirugikan untuk memperjuangkan haknya, maka akan sangat sulit jika seandainya ada yang ingin membawa perkara tersebut ke tingkat yang lebih tinggi. Hal itu adalah bagian dari resiko yang harus ditanggung atas perbuatan yang telah dilakukan.

Dapat ditarik kesimpulan bahwa penyelesaian sengketa atau terjadinya wanprestasi di kalangan masyarakat Desa Gondanglegi Wetan, khususnya dalam praktek gadai lahan pertanian belum ada bahkan tidak ada upaya hukum yang jelas yang sesuai dengan prosedur hukum di Indonesia. Dikarenakan objeknya tidak mempunyai kekuatan hukum. Adapun jika ada yang tekad dengan alasan untuk memperjuangkan hak, maka sama saja dengan melakukan hal yang sia-sia belaka.

Selama ini yang terjadi di kalangan masyarakat Desa Gondanglegi Wetan, mereka menyelesaikan permasalahan gadainya dengan jalan kekeluargaan. Mayoritas dari mereka adalah pasrah atas

35 Suwarno, W awancara (Wates, 22 Maret 2019).

36 Shohib, Wawancara (Mentaraman, 22 Maret 2019). 
nasib rugi atau tertipu yang telah dialami. Bahkan jika ada yang sangat menyedihkan sebagaimana temuan lapangan oleh penulis, yakni mereka yang tidak menyadari jika telah dicurangi, merupakan faktor sumber daya manusia itu sendiri. Paling beruntungnya yang bisa membawa permasalahannya ke tingkat Pemerintahan Desa, setidaknya mereka adalah yang punya pengaruh di dalamnya.

\section{Penutup}

Berdasarkan pembahasan di atas, dapat disimpulkan bahwa mayoritas masyarakat telah memahami bahwa transaksi gadai lahan pertanian merupakan transaksi (akad) yang tidak dibenarkan dalam Syari'ah Islam tetapi pada penerapannya gadai lahan pertanian yang terjadi di Desa Gondanglegi Wetan hanya berdasar kepada hukum kebiasaan (adat) yang telah berlaku secara turun temurun. Hal ini dilakukan sebagai cara untuk menutupi kebutuhan dana yang berjumlah relatif besar dalam waktu yang singkat.

Kedua, tidak adanya ketentuan mengenai peraturan atau penetapan upaya penyelesaian jika terjadi pelanggaran (wanprestasi) dalam pelaksanaan gadai lahan pertanian di Desa Gondanglegi Wetan. Hal ini dikarenakan tidak adanya kekuatan hukum atas transaksi gadai lahan pertanian yang terjadi dalam masyarakat. Pada tingkat Pemerintah Desa pun terkesan tidak mau tahu terhadap masyarakat yang melakukan praktek gadai lahan pertanian dengan dalih mencari aman atas tindakan yang memang sudah jelas dilarang di mata Hukum Negara maupun Hukum Agama. Ketiga, berkaitan 
dengan implikasi (dampak langsung) atas terjadinya praktek gadai lahan pertanian, baik terhadap para pelaku gadai lahan pertanian maupun terhadap lingkungan sekitar meninggalkan kesan yang negatif karena terdapat ketimpangan di dalamnya. Ketimpangan yang dimaksud adalah satu pihak merasa untung dan pihak lain merasa dirugikan, serta pandangan masyarakat yang selalu buruk terhadap orang-orang yang melakukan transaksi gadai lahan pertanian dengan dalih telah diketahui bahwa transaksi tersebut adalah dilarang menurut Hukum Islam.

\section{Daftar Pustaka}

Zuhayli, Wahbah. 2000. Figh Islam wa Adillatubu, J. 6. Damaskus: Darul Fikir.

Sjahdeni, Sutan Remi. 2010. Perbankan Syariab: Produk-produk dan Aspek Hukumnya. Jakarta: Jayakarta Agung Offset.

Antonio, Muhammad Syafi'i. 2001. Bank Syariah dari Teori ke Praktek. Jakarta: Gema Insani Press.

Khosyi'ah, Siah. 2014. Figh Mualamah Perbandingan. Bandung: CV Pustaka Setia.

Muttaqien, Dadan. 2009. Aspek Legal Lembaga Keungan Syari'ah. Cet. 1. Yogyakarta: Safira Insani Press.

Shidiq, Sapiudin. 2017. Fikih Kontemporer. Jakarta: Kecana. Al-Jazairi, Abu Bakar Zabir. 2013. Tafsir Al-Aisar. Buku 1, Cet. 5. Jakarta: Darus Sunnah Press. 
Ash Shiddieqy, Hasbi. 2001. Koleksi Hadis-Hadis Hukum, Cet.3. Jakarta: PT Pustaka Rizki Putra.

Ath-Thayyar Abdullah Muhammad bin, et.al. 2008. Ensiklopedia Figh Muamalah dalam Pandangan 4 Madz̧hab. Yogyakarta: Maktabah Al-Hanif.

Ali, Zainuddin. 2008. Hukum Gadai Syariah. Cet.1. Jakarta: Sinar Grafika.

Hakim, Rahmad. Penerapan Konsep Ta'dib dalam Pembelajaran Ekonomi Syariah, Falah: Jurnal Ekonomi Syariah, Vol. 2, No. 2 (Agustus, 2017), 211-225.

Haroen, Nasrun. 2000. Fiqh Mu'amalah, Cet.1. Jakarta: Gaya Media Pratama.

Hasan, M. Ali. 2003. Berbagai Macam Transaksi Dalam Islam (Fiqh Muamalat). Jakarta: PT Raja Grafindo Persada.

Syafe'i, Rachmat. 2001. Fiqih Muamalah; Untuk UIN, STAIN, PTAIS dan Umum. Bandung: Pustaka Setia.

Suhendi, Hendi. 2016. Fiqh Muamalah. Jakarta: Rajawali Pers.

Mustofa, Ahmad. et.al., 2014. Reorientasi Ekonomi Syariah. Yogyakarta: UII Press.

Karim, Adiwarman A. \& Sahroni, Oni. 2018. Riba, Gharar dan Kaidah-Kaidah Ekonomi Syariah: Analisis Fikih dan Ekonomi. Jakarta: Rajawali Pers.

Karim, Adiwarman A., Bank Islam: Analisis Fikih dan Kenangan. Jakarta: Raja Grafindo Persada, 2004.

Pradja, Juhaya S. 2012. Ekonomi Syariah, Cet. 1. Bandung: Pustaka Setia. 
Bawon Rosyadi, Wawancara. Karang Asem, 16 Maret 2019.

Sri Rahayu, Wawancara. Karang Asem, 17 Maret 2019.

Pondi, Wawancara. Karang Asem, 17 Maret 2019.

Bawon Rosyadi. Wawancara. Karang Asem, 16 Maret 2019.

Ahmad Zaini, Wawancara. Karang Asem, 21 Maret 2019.

Suwarno, Wawancara. Wates, 22 Maret 2019.

Shohib, Wawancara. Mentaraman, 22 Maret 2019.

Ismail, Wawancara. Karang Asem, 16 Maret 2019.

Suparman, Wawancara. Karang Asem, 17 Maret 2019.

Supardi, Wawancara. Wates, 18 Maret 2019.

Faridatul Kholila, Wawancara. Kendayaan, 20 April 2019.

Siti Aminah, Wawancara. Karang Asem, 20 April 2019.

Alfiyah, Wawancara. Wates, 17 Maret 2019.

Sri Rahayu, Wawancara. Karang Asem, 17 Maret 2019.

Subairi, Wawancara. Wates, 19 Maret 2019. 